\title{
The relation between Helicobacter pylori and symptomatic cholelithiasis
}

\section{Helicobacter pylori ve semptomatik kolelitiasis arasındaki ilişki}

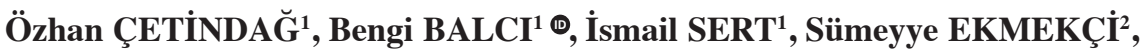 \\ Gülden DINIIZ ${ }^{2} \oplus$, Fuat İPEKÇ $\dot{I}^{1}$

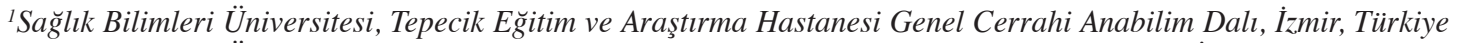 \\ ${ }^{2}$ Sağlık Bilimleri Üniversitesi, Tepecik Eğitim ve Araştırma Hastanesi Patoloji Anabilim Dalı, İzmir, Türkiye
}

\begin{abstract}
Objective: The presence of Helicobacter pylori $(H$. pylori) in biliary tract has recently been discovered. In this study, we aimed to demonstrate the relationship between $H$. pylori, gallbladder diseases and the upper gastrointestinal symptoms by investigating the presence of $H$. pylori in the mucosa of the gallbladder and stomach in patients operated for symptomatic cholelithiasis.

Methods: Hundred and five patients who underwent cholecystectomy for symptomatic cholelithiasis and upper gastrointestinal endoscopic procedure for dyspeptic symptoms were included to this study. Histopathology findings of endoscopic biopsy specimens of the upper gastrointestinal and cholecystectomy material were evaluated for the presence of $\boldsymbol{H}$. pylori using immunohistochemical staining methods with toludine blue (T. blue) and Warthin starry stains (W. starry).

Results: $H$. pylori was identified in the biopsy specimens excised from gallbladders of $28(26.7 \%)$, and gastric mucosa of $37(35.2 \%)$ patients. Any correlation between $H$. pylori positivities in the gastric mucosa and gallbladder specimens could not detected $(\mathrm{p}>0.05, \mathrm{r}=0.051)$. H. pylori was also associated with any specific gallbladder pathology.

Conclusion: Although the presence of $\boldsymbol{H}$. pylori in gallbladder was revealed, we are in need of further studies to demonstrate the relation between $H$. pylori and the formation of gallbladder stones.
\end{abstract}

Keywords: Helicobacter pylori, gallbladder diseases, gastritis

$\ddot{\mathbf{O Z Z}}$

Amaç: Helicobacter pylori'nin (H.pylori) safra yollarında varlığı henüz yeni saptanmıştır. Bu çalışmada, $H$. pylori ile safra kesesi hastalıkları ve üst gastrointestinal semptomlar arasındaki ilişkiyi, semptomatik kolelitiasis nedeniyle opere edilen hastaların safra kesesi ve mide mukozalarında $H$. pylori varlığını araştırarak ortaya koymayı amaçladık.

Yöntem: Semptomatik kolelitiasis nedeniyle kolesistektomi uygulanan ve dispeptik semptomlar nedeniyle üst gastrointestinal endoskopik işlem yapılan 105 hasta çalışmaya dahil edildi. Üst gastrointestinal endoskopik biyopsi ve kolesistektomi patoloji spesimenleri $H$. pylori varlığı açısından Toludine blue (T. blue) ve Warthin starry (W. starry) ile immünohistikimyasal boyama yöntemleri kullanılarak araştırıldı.

Bulgular: H. pylori 28 hastanın $(\% 26,7)$ safra kesesi spesimenlerinde ve 37 hastanın $(\% 35,2)$ mide mukozasında pozitif olarak bulunmuştur. Mide mukozası ve safra kesesi spesimenlerindeki $H$. pylori pozitifliği arasındaki ilişki araştırılmış ve ilişkili bulunmamıştır ( $>00,05, r=0,051)$. H. pylori ayrıca hiçbir spesifik safra kesesi patolojisi ile de ilişkilendirilememiştir.

Sonuç: Her ne kadar safra kesesinde $H$. pylori saptanmış olsa da, H. pylori ve safra kesesi taşları oluşumu arasındaki ilişkiyi ortaya koymak için daha ileri çalışmalara gereksinim vardır.

Anahtar kelimeler: Helicobacter pylori, safra kesesi hastalıkları, gastrit

Alındığı tarih: 07.08.2018

Kabul tarihi: 31.08 .2018

Yazışma adresi: Ass. Bengi Balcı, Kazım Dirik Mah. 357/3 Sokakmyvia Bahçe Sitesi C Blok 3. Kat. No:78, İzmir - Türkiye

e-mail: bengibalci@gmail.com

Yazarların ORCID bilgileri:

B.B. 0000-0002-0630-5097 G.D. 0000-0003-1512-7584 


\section{INTRODUCTION}

Gallbladder diseases are among the most common diseases seen in gastrointestinal system. The prevalence is found to be between 10 to $36 \%$ in autopsy series ${ }^{(1)}$. Gallbladder stones are related with gender, age, ethnicity and comorbid diseases such as obesity, Crohn's disease, hereditary spherocytosis and thalassemia ${ }^{(2)}$.

Although, 40 to $60 \%$ of the patients with gallbladder stones are usually asymptomatic, patients may present with symptoms of chronic cholecystitis (60-70\%), acute cholecystitis (20\%) and acute pancreatitis ${ }^{(2)}$. Gallbladder diseases may also cause symptoms such as dyspepsia, bloating and epigastric pain which can easily be misinterpreted for upper gastrointestinal diseases.

Helicobacter pylori (H. pylori) is a gram negative bacterium which is found to be associated with chronic gastritis, peptic ulcer disease, gastric carcinoma and maltoma ${ }^{(3-5)}$. It has recently been demonstrated that $H$. pylori can also be found in hepatobiliary tract and cause cholesterol gallstones ${ }^{(6,7)}$.

In this study, we aimed to demonstrate the relationship between $H$. pylori, gallbladder diseases and the upper gastrointestinal symptoms by investigating the presence of $H$. pylori in the mucosa of the gallbladder and stomach in patients operated for symptomatic cholelithiasis.

\section{MATERIALS and METHODS}

Between 2012-2015, 105 patients who underwent cholecystectomy for symptomatic cholelithiasis and upper gastrointestinal endoscopic procedure for dyspeptic symptoms, were included in this study. Patients who were under 18 years old, and on proton pump inhibitor (PPI) treatment or received H. pylori eradication treatment were excluded from this study. Patients' demographic features such as age, gender, American Society of Anesthesiologists (ASA) score and comorbid diseases were noted. Clinical features such as preoperative ultrasound, upper GIS endos- copy, gastric endoscopic biopsy results and postoperative pathology reports of gallbladder specimens were investigated retrospectively. Preoperative leukocyte counts, aspartate aminotranspherase (AST), and alanine aminotranspherase (ALT) values were also included in the analysis.

Patients were diagnosed as acute gastritis, chronic gastritis and chronic atrophic gastritis according to their upper gastrointestinal endoscopy reports. Postoperatively, the pathology reports of gallbladder specimens were evaluated and patients were divided into categories of acute cholecystitis, cholesterolosis

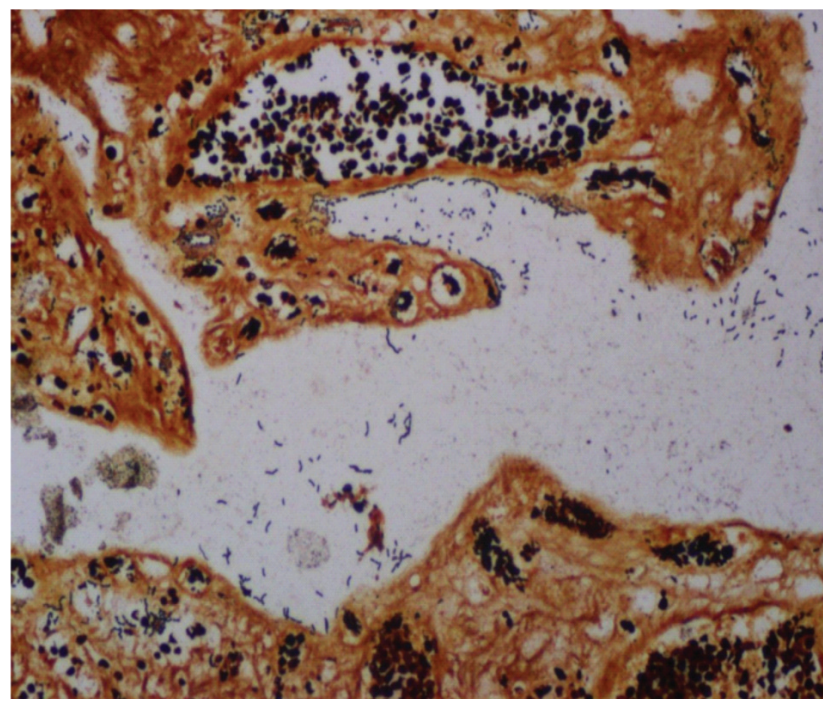

Figure 1. Immunohistochemical staining with W. starry.

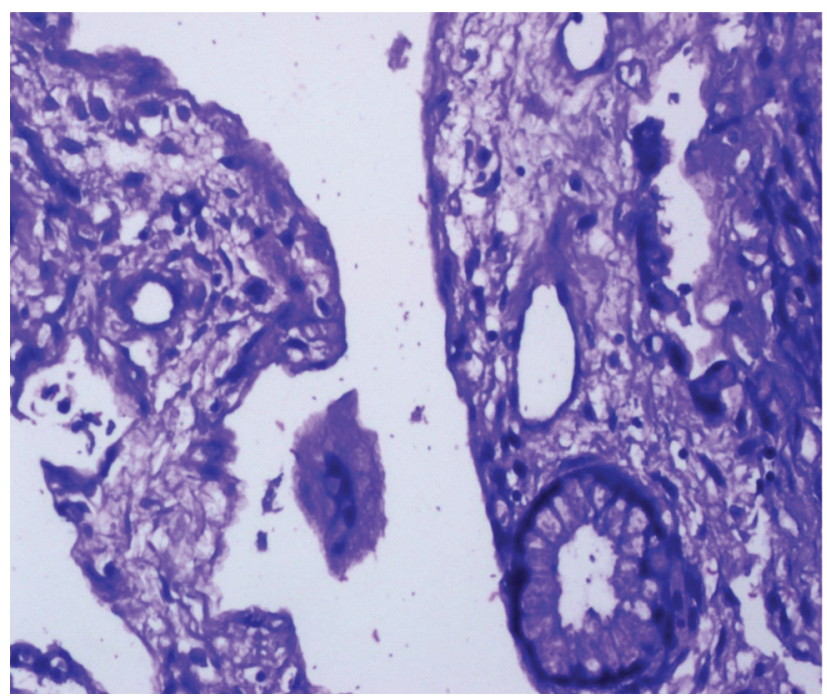

Figure 2. Immunohistochemical staining with T. blue. 
and chronic cholecystitis.

Paraffin-embedded gallbladder tissues from all 105 patients were analyzed for the presence of $H$. pylori using immunohistochemical staining methods by three different pathologists.

As immunohistochemical stains toludine blue ( $\mathrm{T}$. blue) and Warthin starry (W. starry) were used in this study. For each specimen, T. blue and W. starry stains were used separately and the results were noted as $H$. pylori positive and negative (Figure 1,2).

Statistical analyses were evaluated on SPSS 20, using chi-square test, Student's t test, Mann-Whitney U test and Kendall's test. $\mathrm{p}<0.05$ was accepted as statistically significant.

This study was approved by Ethical Committee and all patients' informed consents were taken as written.

\section{RESULTS}

Among 105 patients, 67\% of the patients (N:71) were female and $33 \%$ of them $(\mathrm{N}: 34)$ were male. The age range was between 26 to 78 years, and mean age was $54.9 \pm 11.75$ years. ASA $1(n=45: 42.9 \%)$, ASA 2 $(\mathrm{n}=52: 49.5 \%)$ and ASA $3(\mathrm{n}=8: 7.6 \%)$ scores were estimated for indicated number of patients. Mean preoperative leukocyte count was $8558 \pm 3151 / \mu \mathrm{L}$ (range 2100 to 20.500. The mean AST and ALT values were $40.8 \pm 72.7 \mathrm{U} / \mathrm{L}$ (range, 11 to $689 \mathrm{U} / \mathrm{L}$ ) and $40.7 \pm 59.3 \mathrm{U} / \mathrm{L}$. (range 7 to $411 \mathrm{U} / \mathrm{L}$, respectively.

Patients were evaluated by abdominal ultrasound preoperatively. and gallbladder stones $(n=67: 63.8 \%)$, gallbladder sludge $(n=34: 32.4 \%)$, and acute cholecystitis $(n=4: 3.8 \%)$ were detected in respective number of patients.

Based on upper gastrointestinal endoscopy reports endoscopic findings were found to be normal were found to be normal in 10 patients. Whereas, acute gastritis was detected in 13, chronic gastritis in 54, and chronic atrophic gastritis in 28 patients. H. pylori was identified in the gastric mucosa of 37 (35.2\%) patients.

Laparoscopic cholecystectomy $(n=56)$ and open cholecystectomy $(n=49)$ were also performed. The pathology of gallbladder specimens were evaluated and reported as acute cholecystitis in 14, chronic cholecystitis in 63, and cholesterolosis in 28 patients. In 25 patients chronic cholecystitis and cholesterolosis were found in combination. In 2 patients with acute cholecystitis, adenocarcinoma and pyloric metaplasia were detected.

According to immunohistochemical analyses of the gallbladder and gastric mucosa specimens, patients were divided as gallbladder $H$. pylori positive and negative, and gastric $H$. pylori positive and negative groups. The results obtained using W. starry and $\mathrm{T}$. blue stains were reported as positive and negative, separately. Positive results with one staining methods were accepted as positive. H. pylori was found to be positive in the gallbladder specimens of $28(26.7 \%)$, and negative in 77 patients (73.3\%). Among $28 \mathrm{H}$. pylori positive patients, 17 of them were stained positively with both $\mathrm{W}$. starry and $\mathrm{T}$. blue. However, 20 patients of this group were stained positively only with $\mathrm{T}$. blue and 25 patients only with W. starry.

Staining methods were compared using nonparametric Kendall's correlation test and McNemar's test. Correlation test was found to be significant at $r=0.690$ and $\mathrm{p}<0.001$. W. starry and T. blue stains were compared for detecting rates of $H$. pylori in the mucosa of gallbladder specimens. There were no significant differences between these two methods as for identification of $\mathrm{H}$. pylori in the mucosa of gallbladder specimens ( $>0.05)$ (Table 1).

The relation between $H$. pylori-positivity in the gastric mucosa and gallbladder specimens was inves-

Table 1. Detection rates of $\boldsymbol{H}$. pylori in gallbladder specimens by $\mathrm{T}$. blue and $W$. starry.

\begin{tabular}{lccc}
\hline N=105 & $\begin{array}{c}\text { Gallbladder } \\
\text { H. pylori (-) } \\
\text { N=77 }\end{array}$ & $\begin{array}{c}\text { Gallbladder } \\
\text { H. pylori (+) } \\
\text { N=28 }\end{array}$ & \\
\hline T. BLUE (-) & $77(90.6 \%)$ & $8(9.4 \%)$ & 85 \\
T. BLUE (+) & $0(0 \%)$ & $20(100 \%)$ & 20 \\
W. STARRY (-) & $77(96.3 \%)$ & $3(3.8 \%)$ & 80 \\
W. STARRY (+) & $0(0 \%)$ & $25(100 \%)$ & 25 \\
\hline
\end{tabular}

Toludine blue (T. blue), Warthin starry (W. starry) 
tigated and and any correlation was not detected ( $\mathrm{p}>0.05, \mathrm{r}=0.051)$. However, in multivariate analyses, including age and gender, gallbladder stones and $H$. pylori positivity in the gastric mucosa was found to be significantly interelated (p:0.42) (Table 2).

There was no significant difference for genderrelated findings for $H$. pylori in the gallbladder specimen. $H$. pylori-positivity was detected in $21.1 \%$ of women and $38.2 \%$ in men $(p>0.05)$. Whereas, there was a significant difference for gender-related findings for $H$. pylori in gastric mucosa. H. pylori

Table 2. Comparison of detection rates of $\mathrm{H}$. pylori between the gastric mucosa and the gallbladder specimens $(p>0.05)$.

\begin{tabular}{lccc}
\hline & $\begin{array}{c}\text { Gallbladder } \\
\text { H. pylori }(-) \\
\text { N=77 }\end{array}$ & $\begin{array}{c}\text { Gallbladder } \\
\text { H. pylori }(+) \\
\mathbf{N = 2 8}\end{array}$ & $\mathbf{N = 1 0 5}$ \\
\hline Gastric H.pylori (-) & $51(75 \%)$ & $17(25 \%)$ & $68(100 \%)$ \\
Gastric H.pylori (+) & $26(70.3 \%)$ & $11(29.7 \%)$ & $37(100 \%)$ \\
\hline
\end{tabular}

Table 3. Relation between gallbladder $H$. pylori positivity and gallbladder pathology $(\mathrm{p}=0.205)$.

\begin{tabular}{lccc}
\hline & $\begin{array}{c}\text { Gallbladder } \\
\text { H. pylori (-) } \\
\text { N=77 }\end{array}$ & $\begin{array}{c}\text { Gallbladder } \\
\text { H. pylori (+) } \\
\mathbf{N = 2 8}\end{array}$ & $\mathbf{N = 1 0 5}$ \\
\hline Acute cholecystitis & $9(64.3 \%)$ & $5(35.7 \%)$ & $14(100 \%)$ \\
Chronic cholecystitis & $44(69.8 \%)$ & $\begin{array}{c}19(30.2 \%) \\
4(14.3 \%)\end{array}$ & $28(100 \%)$ \\
Cholesterolosis & $24(85.7 \%)$ & & \\
\hline
\end{tabular}

Table 4. Relation between gastric $H$. pylori positivity and gallbladder pathology $(p=0.591)$.

\begin{tabular}{lccc}
\hline & $\begin{array}{c}\text { Gastric } \\
\text { H. pylori (-) } \\
\mathbf{N = 6 8}\end{array}$ & $\begin{array}{c}\text { Gastric } \\
\text { H.pylori (+) } \\
\mathbf{N = 3 7}\end{array}$ & N=105 \\
\hline Acute cholecystitis & $9(64.3 \%)$ & $5(35.7 \%)$ & $14(100 \%)$ \\
Chronic cholecystitis & $43(68.3 \%)$ & $20(31.7 \%)$ & $63(100 \%)$ \\
Cholesterolosis & $16(57.1 \%)$ & $12(42.9 \%)$ & $28(100 \%)$ \\
\hline
\end{tabular}

Table 5. Relation between the presence of gallbladder stones and $H$. pylori positivity in the gallbladder $(\mathrm{p}=1.000)$ and gastric mucosa $(\mathrm{p}=\mathbf{0 . 0 5 1})$.

\begin{tabular}{|c|c|c|c|c|}
\hline & \multicolumn{2}{|c|}{ Gallbladder } & \multicolumn{2}{|c|}{ Gastric Mucosa } \\
\hline & $\begin{array}{l}\text { H. pylori (-) } \\
\mathbf{N}=77\end{array}$ & $\begin{array}{c}\text { H. pylori }(+) \\
\mathrm{N}=\mathbf{2 8}\end{array}$ & $\begin{array}{c}H . \text { pylori }(-) \\
\mathbf{N}=68\end{array}$ & $\begin{array}{c}\text { H. pylori }(+) \\
\mathbf{N}=37\end{array}$ \\
\hline $\begin{array}{l}\text { Gallbladder } \\
\text { stones (-) }\end{array}$ & $4(80 \%)$ & $1(20 \%)$ & $1(20 \%)$ & $4(80 \%)$ \\
\hline $\begin{array}{l}\text { Gallbladder } \\
\text { stones }(+)\end{array}$ & $73(73 \%)$ & $27(27 \%)$ & $67(67 \%)$ & $33(33 \%)$ \\
\hline
\end{tabular}

-positivity was found in $42.3 \%$ of women and $20.6 \%$ in men $(\mathrm{p}=0.03)$.

$H$. pylori positive and negative groups in gallbladder and gastric mucosa specimens were also compared for age, WBC, AST, ALT, gallbladder wall thickness and length of hospital stay without any statistically significant difference between these parametres.

Patients were also divided according to pathological findings of gallbladder specimens, as acute cholecystitis, chronic cholecystitis and cholesterolosis. Each group was compared for H.pylori -positivity in gallbladder and gastric mucosa and the results were statistically significant at $\mathrm{p}=0.205$ and $\mathrm{p}=0.591$, respectively (Table 3-4).

The correlation between the presence of gallbladder stones and $H$. pylori-positivity in the gallbladder and gastric mucosa was also investigated. There was no significant difference detected and the results were statistically significant at $p=1.000$ and $p=0.051$, respectively (Table 5).

\section{DISCUSSION}

Helicobacter species have been found to be related not only with gastroduodenal diseases, but also hepatobiliary tract pathologies ${ }^{(8-10)}$. Even in many studies that included the same subjects, discordant results have been observed. Fox et al. ${ }^{(11)}$ identified Helicobacter species in bile and gallbladder tissues in patients with chronic cholecystitis, whereas other studies have failed to detect the presence of $H$. pylori DNA in bile or gallbladder tissues from patients with biliary tract diseases ${ }^{(12,13)}$. Regional differences due to variable rates of infection and the changing sensitivity of the various techniques used might be responsible for the differences among reported studies.

Silva et al. ${ }^{(14)}$ reported that $H$. pylori DNA was detected in $50 \%$ of gallbladder tissue samples and $23.3 \%$ of bile samples from patients with cholecystitis, on the other hand no association was observed between the presence of $H$. pylori DNA in the bile and inflammation of the gallbladder mucosa. 
In our study, although we demonstrated the presence of $H$. pylori in gallbladder specimens, no specific gallbladder pathology was found to be associated with $H$. pylori.

On the other hand, an epidemiologic study held in China revealed that $H$. pylori infection had a significant positive association with gallbladder stones, and significant reduction in prevalence of gallbladder stones was observed after eradication of $H$. pylori ${ }^{(15)}$.

$H$. pylori can be identified using combination of different methods including immunohistochemical staining methods with W. starry, T. blue and Giemsa dyes, polymerase chain reaction (PCR), and culture. Bostanoglu et al. ${ }^{(16)}$ used four different methods including culture, histopathology, PCR and immunohistochemical methods for the identification of $H$. pylori in gallbladder mucosa in patients with cholelithiasis. H. pylori could not be detected in neither of methods. Whereas Moricz et al. ${ }^{(17)}$ demonstrated that in patients with chronic cholecystitis, H. pylori-positivity was detected using PCR and Giemsa staining. Similar to our study, no correlation was detected between the presence of $H$. pylori and histological changes in the gallbladder mucosa.

The aim of the study was also to observe the patients with ongoing gastrointestinal symptoms after cholecystectomy. To this end upper gastrointestinal endoscopy was performed in all 105 patients, and harvested gastric mucosa specimens were investigated for the presence of $H$. pylori and the correlation between the $H$. pylori-positivity in the gallbladder and gastric mucosa. Any correlation could not be found between the $H$. pylori-positivity in gastric mucosa and the gallbladder pathologies such as acute and chronic cholecystitis. Also, there was not any correlation detected between gastric and gallbladder H. pylori-positivity.

Attaallah et al. ${ }^{(18)}$ reported the concomitant presence of $H$. pylori in the gastric and gallbladder mucosa in patients operated for symptomatic cholelithiasis, though $H$. pylori was not suggested for the etiology of cholelithiasis. The major limitations of our study were retrospective inclusion of the patients in our study and limited number of patients. Also combining different $H$. pylori identification methods such as PCR and culture besides immunohistochemical methods and having specimens analyzed by the same pathologist would give more accurate results.

Although Helicobacter species have been detected in the biliary tract in many studies, infection of the gallbladder and biliary tract with these bacteria is likely to be an additional factor for the development of gallbladder stones. Concomitant presence of $H$. pylori in the gastric and gallbladder mucosa should be investigated further in larger studies.

\section{REFERENCES}

1. Pham TH., Hunter JG. Gallbladder and the Extrahepatic Biliary System. Schwartz Principles of Surgery $10^{\text {th }}$ Edition. 2015; McGraw-Hill Education.

2. Sayek İ. Sayek Temel Cerrahi. 2013; Güneş Tıp Kitapevi.

3. Kusters JG, van Vliet AHM, Kuipers EJ. Pathogenesis of Helicobacter pylori Infection. Clin Microbiol Rev. 2006 Jul;19(3):449-90. https://doi.org/10.1128/CMR.00054-05

4. Kuipers EJ, Thijs JC, and Festen HP. The prevalence of Helicobacter pylori in peptic ulcer disease. Aliment Pharmacol Ther. 1995;9(Suppl. 2):59-69.

5. Eidt, S., M. Stolte, and R. Fischer. Helicobacter pylori gastritis and primary gastric non-Hodgkin's lymphomas. J Clin Pathol. 1994;47:436-9. https://doi.org/10.1136/jcp.47.5.436

6. Apostolov E, Al-Soud WA, Nilsson I, Kornilovska I, Usenko V, Lyzogubov V, Gaydar Y, Wadström T, Ljungh A. Helicobacter pylori and other Helicobacter species in gallbladder and liver of patients with chronic cholecystitis detected by immunological and molecular methods. Scan J Gastroenterol. 2005;40(1):96-102. https://doi.org/10.1080/00365520410009546

7. Monstein HJ, Jonsson Y, Zdolsek J, Svanvik J. Identification of Helicobacter pylori DNA in human cholesterol gallstones. Scand J Gastroenterol. 2002;37:112-9. https://doi.org/10.1080/003655202753387455

8. Nilsson HO, Mulchandani R, Tranberg KG, Stenram U, Wadström T. Helicobacter species identified in liver from patients with cholangiocarcinoma and hepatocellular carcinoma. Gastroenterology. 2001 Jan;120(1):323-4. https://doi.org/10.1053/gast.2001.21382

9. Kosaka T, Tajima Y, Kuroki T, Mishima T, Adachi T, Tsuneoka N, Fukuda K, Kanematsu T. Helicobacter bilis colonization of the biliary system in patients with pancreaticobiliary maljunction. Br J Surg. 2010 Apr;97(4):544-9. https://doi.org/10.1002/bjs.6907

10. Nilsson HO, Taneera J, Castedal M, Glatz E, Olsson R, Wadström T. Identification of Helicobacter pylori and other Helicobacter species by PCR, hybridization, and partial DNA sequencing in human liver samples from patients with primary sclerosing cholangitis or primary biliary cirrhosis. J Clin Microbiol. 2000 Mar;38(3):1072-6. 
11. Fox JG, Dewhirst FE, Shen Z, Feng Y, Taylor NS, Paster BJ, Ericson RL, Lau CN, Correa P, Araya JC, Roa I. Hepatic Helicobacter species identified in bile and gallbladder tissue from Chileans with chronic cholecystitis. Gastroenterology. 1998 Apr;114(4):755-63. https://doi.org/10.1016/S0016-5085(98)70589-X

12. Bohr UR, Kuestewr D, Meyer F. Low prevalence of Helicobacteraceae in gallstone disease and gallbladder carcinoma in the German population. Clin Microbiol Infect. 2007;13:525-31. https://doi.org/10.1111/j.1469-0691.2007.01690.x

13. Mendez SN, Pichardo R, Gonzalez J, Sanchez H, Moreno M, Barquera E. Lack of association between Helicobacter species colonization and gallstone disease. J. Clin Gastroenterol. 2001;32:138-41. https://doi.org/10.1097/00004836-200102000-00009

14. Silva CP, Pereira-lima JC, Oliveira AG, Guerra JB, Marques DL, Sarmanho L. Association of the presence of Helicobacter in gallbladder tissue with cholelithiasis and cholecystitis. J Clen Microbiol. 2003;41:5615-8. https://doi.org/10.1128/JCM.41.12.5615-5618.2003
15. Zhang FM1, Yu CH1, Chen HT1, Shen Z1, Hu FL1, Yuan $\mathrm{XP1}, \mathrm{Xu}$ GQ1. Helicobacter pylori infection is associated with gallstones: Epidemiological survey in China. World J Gastroenterol. 2015 Aug 7;21(29):8912-9. https://doi.org/10.3748/wjg.v21.i29.8912

16. Bostanoğlu E1, Karahan ZC, Bostanoğlu A, Savaş B, Erden E, Kiyan M. Evaluation of the presence of Helicobacter species in the biliary system of Turkish patients with cholelithiasis. Turk J Gastroenterol. 2010 Dec;21(4):421-7. https://doi.org/10.4318/tjg.2010.0130

17. Moricz Ad1, Melo M, Castro AM, Campos T, Silva RA, Pacheco AM Jr. Prevalence of Helicobacter spp in chronic cholecystitis and correlation with changes on the histological pattern of the gallbladder. Acta Cir Bras. 2010 Jun;25(3):21824. https://doi.org/10.1590/S0102-86502010000300002

18. Attaallah W1, Yener N, Ugurlu MU, Manukyan M, Asmaz E, Aktan AO. Gallstones and Concomitant Gastric Helicobacter pylori Infection. Gastroenterol Res Pract. 2013;2013:643109.

https://doi.org/10.1155/2013/643109. Epub 2013 May 19. 